\title{
Penggemblengan Sumber Islam Sebagai Manifestasi Utama Pembinaan Falsafah Kritikan Sastera Islam Sayyid Sayyid 'Abd al-Raziq: Analisis Karya Manhaj al-Islami fi al-Naqd al-Adabi
}

\author{
The Abolition of Islamic Sources as a Main Manifestation of the Philosophy of Islamic Literary Criticism \\ Sayyid Sayyid ${ }^{c}$ Abd al-Raziq: Analysis of the Book of Manhaj al-Islami fi al-Naqd al-Adabi \\ Mohd Adi Amzar Muhammad Nawawia ${ }^{*}$, Mohd Fahimi Zakariab \\ aFakulti Pengajian Bahasa Utama, Universiti Sains Islam Malaysia, 71800 Nilai, Negeri Sembilan \\ b Akademi Pengajian Bahasa, Universiti Teknologi Mara, 40450 Shah Alam, Selangor \\ *Corresponding author: adiamzar@usim.edu.my
}

Article history

Received: 2020-12-02 Received in revised form: 2021-06-11 Accepted: 2021-07-02 Published online: 2021-10-30

\begin{abstract}
This study aims to look at the fusion of Islamic sources applied by Sayyid Sayyid cAbd al-Raziq as his main work in developing a unique and distinctive Islamic literary philosophy. On the one side, it is his effort and reflection on the refinement of the philosophical framework of Islamic literature that is considered to be entirely non-Islamic and largely dependent on Western ideas. As a result there are significant contradictions in Islamic values and this has prompted al-Raziq to produce a work that refines these issues. This study applied qualitative methods in the design of content analysis by analyzing the primary source, Manhaj al-Islami fi alNaqd al-Adabi. The findings of the study have found that al-Raziq has optimally used Islamic sources as his primary vehicle in producing a philosophy of literary criticism that is truly Islamic. This is reflected in his efforts through the fusion of Islamic sources including the Qur'an, Hadith and also ethical interpretations in the scope of his philosophical debates including al-Turath al-Islami, al-Turath al-Jabili and al-Turath al-Madi.
\end{abstract}

Keywords: Criticism, Islamic literature, source, Sayyid Sayyid cAbd al-Raziq, philosophy

\section{Abstrak}

Kajian ini bertujuan untuk melihat penggemblengan sumber Islam yang diaplikasikan oleh Sayyid Sayyid cAbd al-Raziq sebagai pemanifestasian utama beliau dalam membina falsafah kritikan sastera Islami yang unik dan tersendiri. Dari satu sudut, ia merupakan usaha dan refleksi beliau terhadap pemurnian semula kerangka falsafah kritikan sastera Islami yang disifatkan sebagai tidak islami secara sepenuhnya dan banyak bergantung kepada idea dan tasawur Barat. Hasilnya wujud percanggahan dan kontradiksi yang ketara dengan nilai Islam dan ini telah menggerakkan al-Raziq untuk menghasilkan satu karya yang memperhalusi berkenaan permasalahan ini. Kajian ini telah menggunakan kaedah kualitatif menerusi reka bentuk analisis kandungan dengan menganalisis sumber primer iaitu Manbaj al-Islami fi al-Naqd al-Adabi. Dapatan kajian telah mendapati bahawa al-Raziq telah menggunakan secara optimum sumber Islam sebagai wahana utama beliau dalam menghasilkan falsafah kritikan sastera yang berpaksikan Islam yang sebenar. Ini dapat dilihat dengan usaha beliau menerusi penggemblengan sumber Islam meliputi Al-Qur'an, Hadith dan juga penginterpretasian berdasarkan etika dalam skop perbahasan falsafah beliau yang meliputi al-Turath al-Islami, al-Turath al-Jabili dan al-Turath al-Madi.

Kata Kunci: Kritikan, sastera Islam, sumber, Sayyid Sayyid cAbd al-Raziq, falsafah. 


\subsection{PENDAHULUAN}

Makalah ini mengkaji serba sedikit berkenaan sumbangan Sayyid Sayyid 'Abd al-Raziq (selepas ini akan dirujuk sebagai al-Raziq) dalam memperkasakan metodologi dan falsafah kritikan sastera Islami menerusi karya yang dihasilkan beliau iaitu Manbaj al-Islami fi al-Naqd alAdabi. Berkaitan dengan al-Raziq, beliau merupakan salah seorang tokoh yang bertanggungjawab menghasilkan karya tersebut dan telah menampilkan sedikit sisi berlainan berkenaan falsafah kritikan sastera Islami yang lebih bersifat progresif dan mengikut acuan Islam yang sebenar. Makalah ini akan melihat dengan lebih dekat lagi bagaimana al-Raziq berinteraksi dan mengaplikasikan sumber Islam yang terdiri daripada Al-Qur'an dan Hadith dalam menggarap idea dan falsafah beliau dalam wacana kritikan sastera Islami. Oleh yang demikian, perbahasan makalah ini akan dicerakinkan kepada beberapa sub topik iaitu pertama untuk meninjau latar belakang falsafah kritikan sastera Islami al-Raziq yang dimanifestasikan menerusi karya Manhaj alIslami fi al-Naqd al-Adabi. Kedua, akan menyoroti skop falsafah kritikan sastera Islami dalam karya yang sama dan yang terakhir analisis menyeluruh berkenaan penggemblengan sumber Islam yang dibuat oleh al-Raziq dalam menghasilkan satu pemikiran falsafah kritikan sastera Islami yang berwibawa dan unggul.

\subsection{LATAR BELAKANG FALSAFAH KRITIKAN SASTERA ISLAM AL- RAZIQ DAN KARYA MANHAJ AL-ISLAMI FI AL-NAQD AL-ADABI}

Al-Raziq muncul dengan falsafah kritikan sastera Islami sejajar dengan penghasilan buku Manhaj al-Islami fi al-Naqd al-Adabi yang dihasilkan beliau pada tahun 2001. Secara asasnya, buku yang mempunyai halaman sebanyak 183 mukasurat ini telah memperhalusi dan memperincikan beberapa isu dan permasalahan yang membelenggu dunia sastera Islami dan kritikan secara khusus yang kelak akan dibincangkan secara tuntas dan menyeluruh dalam makalah ini. Idea dan falsafah kritikan sastera Islami al-Raziq yang dijelmakan secara langsung dalam buku tersebut juga boleh dianggap sebagai unik dan berani kerana terdapat beberapa kritikan yang dilakukan oleh beliau secara langsung terhadap beberapa figura terkenal dalam bidang kesusasteraan Islami. Secara keseluruhannya, kesemua idea dan falsafah yang diterapkan oleh al-Raziq merupakan faktor dan sebab utama kepada kelahiran idea beliau secara langsung. Dalam erti kata yang lain, terdapat faktor dan sebab utama yang menggerakkan pemikiran al-Raziq dalam merencanakan dan menyusun beberapa idea sehingga melahirkan falsafah kritikan sastera Islami beliau.

Dalam melihat faktor utama yang membawa kepada kemunculan falsafah beliau ini, al-Raziq telah memperjelaskan dengan panjang lebar dalam bahagian pendahuluan buku yang dikarang oleh beliau tersebut. Jelas beliau, faktor utama kepada pengasasan falsafahnya adalah disebabkan kerana ketiadaan dan ketidakwujudan metodologi kritikan sastera Islami yang bersifat tulen (alRaziq 2002:8). Ini secara tidak langsung telah menyebabkan berlakunya pengaplikasian dan penerapan metodologi kritikan yang bersumberkan Barat yang pada asasnya mempunyai skema nilai yang amat bersalahan dengan Islam terutamanya dalam aspek prinsip mahupun fahaman (alRaziq 2002:8). Menyentuh berkenaan permasalahan yang disentuh oleh al-Raziq berkaitan ketiadaan metodologi kritikan yang tulen, ia bukanlah perkara baru bahkan pernah diutarakan oleh sarjana terkenal dalam bidang ini di dunia Arab iaitu 'Imad al-Din Khalil. 'Imad al-Din Khalil dalam satu makalah beliau yang ditulis pada tahun 1998 telah menyebut dengan jelas bahawa kekaburan dan kekusutan yang membelenggu para sasterawan Islam terhadap kegiatan sastera mereka telah menyumbang kepada kemunduran dan pengabaian secara langsung terhadap pembinaan metodologi kritikan sastera Islami (Khalil 1998:20). Malahan dari satu segi, 
pengabaian secara langsung terhadap pemerkasaan metodologi kritikan tersebut telah membawa kepada satu penafsiran bahawa Islam itu hanyalah sekadar berbentuk piawaian semata-mata bukan sebagai aliran atau mazhab utama dalam kesusasteraan moden. Piawaian yang dimaksudkan itu juga hanya sekadar pandangan yang diasaskan berdasarkan nilai Islam yang tetap bagi menyerlahkan sastera itu didokongi oleh Islam yang dirujuk menerusi nas Al-Qur'an (Khalil 1998:20-21).

Oleh yang demikian, merujuk kepada faktor utama yang dibangkitkan oleh al-Raziq iaitu ketiadaan metodologi kritikan sastera Islami yang tulen, menjadi satu kemestian dan kewajaran bagi mengakarkan dan memperhalusi kembali metodologi kritikan sastera Islami yang telah dibina oleh para sarjana dan sasterawan dalam lapangan ini. Umum mengetahui bahawa tradisi kritikan sastera Islami secara asasnya telah dibina oleh para sarjana lampau seperti Sayyid Qutb, Abu Hassan Al-Nadwi, Muhammad Qutb, Najib Kilani dan lain-lain bahkan merekalah antara figura yang gigih mengembalikan tradisi Islam khususnya dalam bidang kesusasteraan (Batahir 1998:100). Bahkan tidak dinafikan mereka juga antara tokoh yang kuat menentang pemikiran dan ideologi Barat serta berusaha untuk mengeluarkan umat Islam daripada kepompong tersebut seterusnya menjernihkan kembali pemikiran umat Islam atas landasan yang sebenar (Batahir 1998:100). Walaupun demikian, dalam usaha dan langkah dalam menyediakan satu bentuk kritikan sastera yang bersumberkan Islam yang tulen, masih terdapat beberapa kekurangan dan ketidakjelasan di kalangan para sarjana tersebut khususnya dalam pengaplikasian dan pemanfaatan sumber Islam seperti Al-Qur'an, Hadis dan juga sumber bukan Islam. Inilah yang menjadi fokus dan isu utama yang ditangani sepenuhnya oleh al-Raziq dalam pencernaan falsafah kritikan sastera Islami beliau menerusi buku Manhaj al-Islami fi al-Naqd al-Adabi.

\subsection{SKOP FALSAFAH KRITIKAN SASTERA ISLAMI AL-RAZIQ DALAM MANHAJ AL-ISLAMI FI AL-NAQD AL-ADABI}

Seperti yang diketahui, fokus utama perbahasan falsafah kritikan sastera Islami al-Raziq adalah untuk memberi penumpuan terhadap kaedah Islam yang sebenar dalam berurusan atau berinteraksi dengan al-Turath al-Islami dan al-Turath ghayr al-Islami. Menyentuh berkenaan al-Turath al-Islami, ia ditakrifkan sebagai segala yang diwarisi daripada generasi terdahulu dan lampau berkenaan kepercayaan, tradisi keilmuan yang bertitik tolak daripada dua sumber pegangan yang tertinggi dalam Islam iaitu Al-Qur'an dan Hadith (al-Raziq 2002:13). Manakala al-Turath ghayr alIslami pula menurut al-Raziq (2002:14) boleh difahami sebagai kesemua kesan yang wujud pada zaman Jahiliyah atau sebelum kedatangan Islam serta tamadun-tamadun lampau seperti Mesir Purba, Yunani, Rom, dan Parsi. Kesemua kesan yang wujud pada tinggalan lampau ini boleh diinterpretasikan sebagai semua kegiatan keilmuan, keintelektualan, dan pemikiran yang dilakukan oleh manusia yang hidup pada era tersebut. Berdasarkan falsafah kritikan sastera Islami al-Raziq yang bersumberkan daripada buku Manhaj al-Islami fi al-Naqd al-Adabi, wujud tiga skop utama yang diberi perhatian oleh beliau berkenaan kaedah Islam dalam berinteraksi iaitu pertama terhadap al-Turath al-Islami, kedua al-Turath al-Jahili dan yang ketiga al-Turath al-Madi. Menyentuh berkenaan al-Turath al-Jahili, secara asasnya ia merangkumi segala jenis pengetahuan, keilmuan, adat kebudayaan, kepercayaan, pegangan dan juga pengamalan oleh masyarakat Arab Jahiliyah sebelum muncul sinar Islam yang dibawa oleh junjungan Nabi Muhammad S.A.W (al-Raziq 2002:113). Manakala untuk al-Turath al-Madi, ia boleh difahami sebagai satu bentuk pengetahuan, ilmu, seni, falsafah, aliran, pegangan dan juga pemikiran yang terdapat dalam tamadun lampau serta peradaban Barat yang sedang mengalami perkembangan pada masa kini (al-Raziq 2002:123). Ini juga termasuklah ideologi pemikiran dan kepelbagaian aliran dalam kesusasteraan moden yang pada realitinya tidak bertitik tolak dari Islam secara langsung seperti aliran realisme, 
eksistensialisme, simbolisme dan lain-lain lagi. Kedua-dua turath itu juga pada asalnya merupakan dua komponen yang membentuk al-Turath ghayr al-Islami.

Sehubungan dengan itu, dapat disimpulkan bahawa al-Raziq dalam falsafahnya telah menonjolkan segmen-segmen yang memperlihatkan keterbukaan Islam sebagai satu kaedah utama dalam mengkritik setiap yang terbit khususnya bersumberkan al-Turath al-Islami. Ini dapat dilihat menerusi perbahasan beliau mengenai kaedah berinteraksi dengan al-Turath al-Islami merangkumi lima puluh peratus daripada keseluruhan perbahasan dalam buku Manhaj al-Islami fi al-Naqd al-Adabi. Ini kerana masih terdapat kekaburan dan isu yang menyelubungi sastera Islami dan kritikan yang memerlukan transformasi dan pengakaran semula serta rekonstruksi agar ia benar-benar menjadi sastera Islami yang berwajah tulen dan bebas daripada unsur-unsur tashkik. Keadaan ini sama sekali berbeza dengan al-Turath al-Jabili dan juga al-Turath al-Madi. Ini kerana menurut al-Raziq (2002:8), walaupun pada dasarnya kedua-dua komponen ini terbentuk daripada unsur dan kesan yang tidak berlatar belakangkan Islam secara langsung, ini tidak bermakna ia perlu ditolak secara mutlak. Hal ini kerana masih terdapat ruang dan bentuk yang masih boleh dimanfaatkan menerusi dua komponen tersebut selagi mana tidak bercanggah dan bertentangan dengan prinsip Islam yang telah disyariatkan secara jelas menerusi Al-Qur'an dan Hadith. Secara umumnya, skop perbahasan falsafah kritikan sastera Islami al-Raziq boleh difahami sebagai satu bentuk penelitian dan pemerhatian yang bersifat kritikal dan analitikal tentang bagaimana Islam berinteraksi dengan al-Turath al-Islami itu sendiri yang merangkumi Al-Qur'an dan Hadith. Juga, untuk melihat bagaimana sudut pandang dan penerimaan Islam ketika berhadapan dengan alTurath al-Jabili dan al-Turath al-Madi yang keseluruhannya adalah bersumberkan Barat dan tidak berorientasikan Islam secara langsung. Justeru, ketiga-tiga komponen utama ini dihubungkan secara langsung dalam lapangan kesusasteraan bagi meninjau perspektif dan metodologi Islam yang tersendiri dalam menanggapi isu dan permasalahan yang wujud dalam perbahasan tiga komponen tersebut.

\subsection{PENGGEMBLENGAN SUMBER ISLAM DALAM FALSAFAH KRITIKAN SASTERA ISLAM AL-RAZIQ}

Dalam melihat bahagian ini, terdapat beberapa sumber Islam yang telah dikenal pasti digunakan secara langsung oleh al-Raziq dalam membentuk falsafah kritikan beliau antaranya AlQur'an dan Hadith. Juga akan dibahaskan secara terperinci berkenaan ruang penginterpretasian sumber Islam dalam lingkungan skop perbahasan falsafah kritikan beliau iaitu berkenaan alTurath al-Islami, al-Turath al-Jahili dan al-Turath al-Madi. Perbahasan pada bahagian seterusnya akan menumpukan secara terus berkenaan Al-Qur'an sebagai sumber Islam yang paling tinggi dan berautoriti yang digemblengkan oleh al-Raziq secara langsung dalam falsafah kritikan sastera Islami beliau.

\subsection{Al-Qur'an}

Menurut Zulkarnain Mohamed (2010:93), Al-Qur'an merupakan wahyu dan kalam Allah S.W.T yang perlu dipelihara dan diletakkan pada kedudukan yang tertinggi mengatasi sumbersumber yang lain. Pengiktirafan sebagai kedudukan yang tertinggi itu mestilah diaplikasikan sebagai sumber rujukan yang utama dan paling berautoriti mengatasi sumber-sumber yang lain. Ini kerana, pada Al-Qur'an itu sendiri merupakan sebuah manual panduan untuk umat manusia menguruskan kehidupan di muka bumi ini dan juga merupakan sumber hidayah yang paling tertinggi disediakan bagi mereka untuk membezakan antara kebenaran dan kebatilan. Hakikat kebenaran ini jelas dinukilkan oleh Allah S.W.T melalui firman-Nya dalam surah Al-Baqarah: 


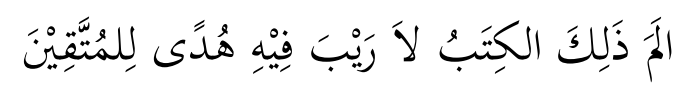

Maksudnya:

Alif, Laam, Miim. Kitab Al-Qur'an ini, tidak ada sebarang syak padanya (tentang datangnya dari Allah dan tentang sempurnanya); ia pula menjadi petunjuk bagi orangorang yang (hendak) bertaqwa.

Dalam konteks al-Raziq, keseluruhan kehidupan beliau banyak dicorakkan oleh AlQur'an. Ini terbukti dengan keupayaan beliau menghafal keseluruhan Al-Qur'an ketika usia muda lantas telah mewarnai corak pemikiran beliau yang cenderung kepada pengamalan Islam yang komprehensif dan cinta kepada ilmu pengetahuan (al-Raziq 2015). Sikap beliau yang begitu cintakan ilmu dapat disoroti menerusi kegigihan dan kesungguhan beliau menyelesaikan pengajian sarjana walaupun terpaksa berulang-alik hampir tiga puluh kilometer setiap hari dari kampung ke universiti yang terletak di bandar Assiut (al-Raziq 2015). Kegigihan dan keseriusan beliau ini secara tidak langsung telah mencorak dan mewarnai pemikiran dan tindakan dalam segenap segi dalam kehidupan beliau. Ini juga termasuk dalam karya penulisan beliau terutamanya buku Manhaj al-Islami fi al-Naqd al-Adabi yang menjadi gagasan dan idea utama dalam menterjemahkan konsep sastera Islami yang lebih bersifat kritis dan analitikal. Berdasarkan pengamalan dan pengalaman beliau menjadikan Al-Qur'an sebagai medium dan sumber utama dalam penerokaan keilmuan bermula sejak kecil hinggalah di saat hembusan nafas terakhir beliau, kesan ini dapat dilihat daripada pengambilan Al-Qur'an sebagai sumber ilmu yang paling tertinggi oleh beliau khususnya dalam merangka falsafah kritikan sastera Islami tersebut.

Antara ayat Al-Qur'an yang digunakan oleh al-Raziq dalam membentuk idea sastera Islami beliau adalah ketika membahaskan berkenaan konsep interaksi antara sastera dan al-Turath al-Islami. Dalam konteks perbahasan yang lebih khusus lagi, al-Raziq cuba menggali hubungan interaksi yang wujud antara sastera dan hukum fiqh mengikut acuan Islam yang sebenar. Berdasarkan situasi ini, beliau telah menggemblengkan dua ayat Al-Qur'an iaitu dari surah AlMaa'idah dan surah Al-A'raaf untuk menggambarkan jalinan dan keterikatan yang kuat bagi mendokong hujah yang dikemukakan beliau berdasarkan fenomena yang telah disebutkan seperti di atas. Kedua-dua ayat Al-Qur'an boleh disoroti seperti di bawah:

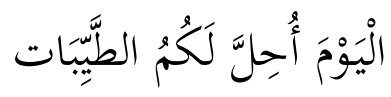

Maksudnya:

Pada masa ini dihalalkan bagi kamu (memakan makanan) yang lazat-lazat serta baikbaik.

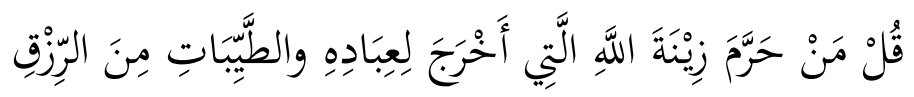

Maksudnya:

Katakanlah (wahai Muhammad): "Siapakah yang (berani) mengharamkan perhiasan Allah yang telah dikeluarkanNya untuk hamba-hambaNya, dan demikian juga bendabenda yang baik lagi halal dari rezeki yang dikurniakanNya?

Kedua-dua ayat Al-Qur'an ini telah dijadikan sumber dan sandaran utama oleh al-Raziq dalam memperjelaskan idea beliau khususnya dalam menginterpretasikan hubungan interaksi 
antara sastera dan hukum fiqh. Dalam isu ini, al-Raziq (2002:19-21) berpandangan bahawa dalam hukum fiqh telah jelas hukum-hukum yang telah termaktub dalam Islam seperti halal, haram, harus dan lain-lain. Begitu juga apabila wujud interaksi antara hukum fiqh dengan kegiatan sastera maka perlulah dilaksanakan dengan berhati-hati ketika proses pengeluaran hukum tersebut agar ia selari dan bertepatan dengan fungsi sastera itu sendiri. Dalam erti kata lain, pengeluaran sesuatu hukum itu ke atas kegiatan sastera perlulah melalui proses kajian dan penelitian yang mendalam oleh pakar-pakar dalam bidang fiqh dengan mengambil kira pelbagai aspek sama ada mampu membawa manfaat atau mengundang keburukan. Ini kerana wujud pentafsiran hukum yang dilakukan tidak bertepatan dengan kaedah sebenar dalam menilai kegiatan bersastera menurut kerangka Islam yang sebenar (al-Raziq 2002:21). Walhal dalam masa yang sama, tidak dinafikan bahawa kegiatan bersastera itu sendiri pada hakikatnya adalah sesuatu yang indah dan mampu untuk memberikan hiburan dan kelapangan kepada keseluruhan manusia. Malahan unsur keindahan dengan sastera merupakan dua perkara yang tidak dapat dipisahkan sama sekali dan saling memenuhi antara satu sama lain. Namun pada satu segi yang lain, keindahan yang wujud dalam kerangka sastera itu memerlukan penilaian dan tapisan yang rapi mengikut penilaian Islam dan syariat. Keindahan yang wujud dalam sastera seharusnya tidak disalah gunakan oleh para sasterawan untuk menyebarkan ideologi mereka yang bersalahan dengan Islam ataupun mempromosikan keindahan yang hanya bersifat luaran namun tidak mengandungi nilai pengajaran yang boleh diambil manfaat.

Justeru itu, al-Raziq (2002:22) menegaskan dalam hubungan interaksi antara hukum fiqh dengan pengaplikasian dalam kerangka sastera yang bertitik tolak dengan unsur keindahan, ia perlu diperhalusi dengan sedalam-dalamnya dalam erti kata mampu membezakan antara yang indah dan yang buruk. Kedua-dua istilah ini juga perlu direnungi dan diletakkan dalam timbangan Islam agar keindahan sebenar yang berpaksikan tauhid kepada Allah S.W.T dapat dijelmakan. Sementara itu, keburukan yang hakiki perlu dielakkan walaupun pada realitinya ia bersifat indah pada struktur luaran menerusi gaya bahasa mahupun pemilihan diksi. Ini kerana, ia tidak menggambarkan nilai sastera yang sepatutnya dan jauh daripada kriteria sastera Islami yang sebenar apabila hanya mementingkan struktur keindahan luaran dan mengabaikan mesej dan perutusan yang sepatutnya dititik beratkan terlebih dahulu. Dalam konteks interaksi antara hukum fiqh dengan sastera yang menampilkan keindahan yang dibenarkan oleh syarak, menurut al-Raziq (2002:21), ia tergolong dalam kategori perkara yang wajib dilakukan dan dilaksanakan. Berbeza dengan keindahan yang bersifat palsu dan mendedahkan kepada keburukan dan kebinasaan, ia merupakan perkara yang haram serta perlu dijauhi dan ditinggalkan serta merta. Berdasarkan kepada dua ayat Al-Qur'an iaitu surah al-Maa'idah (5:4) dan surah al-A'raaf (7:32) yang digunakan oleh al-Raziq sebagai sumber hujahan dalam menjustifikasikan idea beliau berkenaan konsep interaksi antara sastera dengan al-Turath al-Islami, dapat difahami bahawa wujud hubungan yang signifikan antara kedua-dua ayat tersebut dengan konteks idea yang dibina oleh beliau. Ini dapat difahami secara umum mengenai maksud kedua-dua ayat tersebut yang menyatakan bahawa Allah S.W.T telah mengurniakan alternatif terbaik untuk umat manusia tidak kira daripada aspek pemakanan mahupun rezeki-rezeki yang lain. Dalam konteks falsafah alRaziq, beliau cuba memberikan interpretasi dan tafsiran bahawa dengan tersedianya sastera yang mengandungi nilai keindahan sebenar yang membawa kepada ketauhidan dan pengabdian diri kepada Allah S.W.T, mengapa masih wujud sesetengah manusia yang tertipu dengan keindahan sastera yang bersifat luaran dan tidak hakiki? Dan yang lebih malang, sastera yang dijadikan pujaan itu tidak mencernakan satu nilai yang positif malahan mengajak khalayak manusia bertuhankan nafsu dengan pengamalan nilai dan ideologi yang bertentangan dengan Islam. 
Selain itu, al-Raziq juga ada memetik ayat-ayat Al-Qur'an yang lain sebagai sumber hujahan dan pembentukan falsafah kritikan sastera Islami beliau. Ini dapat dilihat menerusi falsafah dan idea beliau yang menyentuh mengenai etika atau prinsip berurusan antara sastera dengan sumber tertinggi Islam iaitu Al-Qur'an. Dalam perbahasan ini, al-Raziq telah memetik dua potongan ayat Al-Qur'an daripada surah Faatir (35:32) dan juga surah Al-A'raaf (7:169) yang boleh dilihat menerusi pemaparan di bawah:

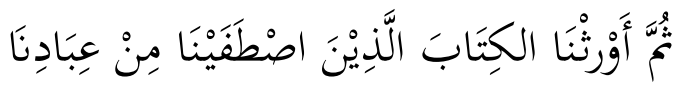

Maksudnya:

Kemudian Kami jadikan Al-Qur'an itu diwarisi oleh orang-orang yang Kami pilih dari kalangan hamba-hamba Kami

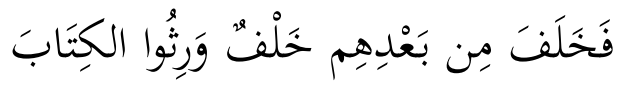

Maksudnya:

Maka mereka kemudiannya digantikan oleh keturunan-keturunan yang jahat yang mewarisi Kitab (Taurat).

Rasional pemilihan kedua-dua ayat ini oleh al-Raziq sebagai sumber falsafah khususnya dalam isu etika berurusan antara sastera dengan Al-Qur'an adalah untuk menjustifikasikan kritikan beliau dalam menafikan sebahagian pandangan yang dikemukakan oleh sasterawan muslim. Dalam isu ini, menurut al-Raziq (2002:40), sebahagian mereka mendakwa bahawa AlQur'an dan Hadith itu bukanlah merupakan sesuatu yang diwarisi atau merupakan sebuah warisan yang ditinggalkan bahkan kedua-duanya merupakan wahyu Ilahi yang diturunkan untuk diamalkan tidak kira masa dan tempat. Dalam konteks warisan yang difahami oleh sebahagian mereka tersebut, ia jelas bertentangan dengan pandangan al-Raziq yang diperkuatkan dengan pengambilan dalil Al-Quran daripada surah Faatir dan surah Al-A'raaf. Ini kerana menurut alRaziq (2002:41), warisan yang dimaksudkan bukanlah warisan yang berbentuk ilmiah mahupun warisan yang berbentuk kesusasteraan yang lahir daripada pemikiran manusia. Warisan yang dimaksudkan dalam konteks yang sebenar adalah merujuk kepada pengambilan kedua-dua sumber tertinggi ini sebagai satu perlembagaan dan metodologi yang utama dalam kehidupan manusia dan bukan sekadar sebagai sebuah kitab yang mengandungi nilai-nilai kebaikan dan pengajaran. Hakikatnya, kedua-dua sumber tertinggi dalam Islam ini merupakan warisan, namun bukan melalui kefahaman yang menyatakan kedua-dua sumber tersebut merupakan warisan yang mengandungi nilai-nilai ilmiah, pengajaran mahupun unsur-unsur gaya bahasa sastera di dalamnya, bahkan melangkaui lebih jauh daripada itu sebagai satu panduan dan perlembagaan tertinggi yang amat diperlukan oleh umat manusia dalam kehidupan mereka.

\subsection{Hadith}

Sumber kedua yang digunakan oleh al-Raziq dalam pembentukan falsafah kritikan sastera Islami beliau selepas Al-Qur'an adalah menerusi penggunaan Hadith. Ini dapat dilihat menerusi pengaplikasian dua Hadith ketika membahaskan berkenaan pengenalan kepada tatacara berinteraksi dengan al-Turath al-Islami. Petikan daripada al-Raziq (2002:17-18) dapat dilihat seperti yang tertera di bawah: 


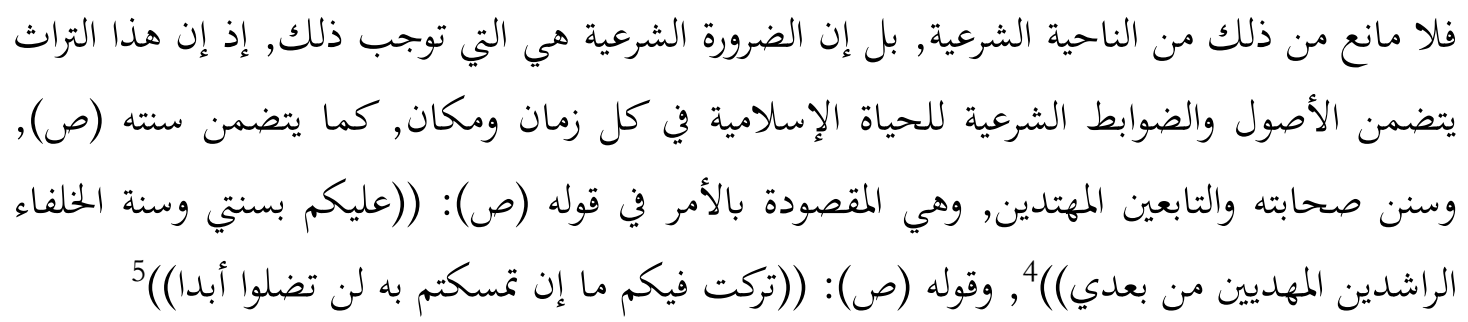

Terjemahan:

Tiada halangan sama sekali mengikut konteks syarak, bahkan menjadi satu keperluan yang mewajibkan ia supaya dilaksanakan sekiranya turath itu mengandungi asas dan panduan syariat untuk kehidupan yang berteraskan Islam pada setiap masa dan tempat. Sebagaimana yang terkandung dalam sunnah Nabi Muhammad S.A.W, sahabat dan para tabi'in berdasarkan sabda Baginda S.A.W yang bemaksud "Hendaklah kamu berpegang kepada sunnahku dan sunnah Khulafa al-Rasyidin selepasku yang diberi bimbingan dan panduan oleh Allah S.W.T" dan juga "Aku tinggalkan kepada kamu, jika kamu berpegang teguh kepadanya, kamu tidak akan sesat buat selama-lamanya".

Merujuk kepada teks al-Raziq di atas seperti yang tertera dalam buku Manhaj al-Islami fi alNaqd al-Adabi, beliau secara jelas telah mengutip dua buah Hadith untuk digunakan sebagai sumber dalam pencernaan falsafah kritikan sastera Islami beliau. Kedua-dua Hadith tersebut ialah dan juga ((كليكم بسنتي وسنة الخلفاء الراشدين المهديين من بعدي))( Melihat kepada konteks penggunaan kedua-dua Hadith sebagai sumber hujahan dan sokongan al-Raziq, ia ternyata penting dalam menjustifikasikan idea beliau khususnya dalam perbahasan mengenai kaedah berinteraksi dengan al-Turath al-Islami. Ini kerana berdasarkan kepada hujahan beliau, ternyata keperluan untuk menitik beratkan perbahasan ini dalam kerangka pengakaran semula sastera Islami merupakan sesuatu yang amat penting dan sukar untuk dipisahkan (al-Raziq 2002:17). Ini disebabkan al-Turath al-Islami yang merupakan himpunan kepercayaan, kebudayaan, adat, seni yang diwarisi oleh golongan-golongan terdahulu yang bersumberkan Al-Qur'an dan Hadith (al-Raziq 2002:13) merupakan warisan Islam yang ditinggalkan untuk tatapan umat yang akan datang. Bertitik tolak dengan itu, ia merupakan khazanah yang sangat berharga dan perlu dipelihara serta diamalkan oleh golongan yang terkemudian. Merujuk kepada elemen pengamalan al-Turath al-Islami ini, pada hakikatnya ia merupakan sesuatu yang perlu direalisasikan dalam kehidupan seharian kerana ia amat berkait rapat dengan kebudayaan Islam turun-temurun selagi mana ia tidak bertentangan dengan syariat. Ini yang ditekankan oleh al-Raziq dalam memerihalkan berkenaan kedudukan pengamalan al-Turath al-Islami tersebut yang mempunyai taraf yang sama penting dengan keperluan seseorang menjadikan Al-Qur'an dan Hadith sebagai panduan utama dalam kehidupan (al-Raziq 2002:17-18). Maka tidak hairanlah menerusi perbahasan ini, al-Raziq memetik dua Hadith yang memperincikan mengenai kepentingan berpegang teguh kepada Al-Qur'an dan Hadith sebagai sumber hujahan bagi menjustifikasikan idea beliau tentang kepentingan menitik beratkan al-Turath al-Islami dalam kerangka pengakaran semula sastera Islami yang lebih efektif.

\subsection{Ruang Penginterpretasian Sumber Islam Dalam Falsafah Kritikan al-Raziq}

Menyentuh berkenaan penginterpretasian sumber Islam oleh al-Raziq, ia berkait rapat dengan sejauh mana beliau menginterpretasikan dan mengaplikasikan kefahaman beliau terhadap Islam yang bersumberkan Al-Qur'an dan Hadith sebagai ilham wahyu yang tertinggi dan paling berautoriti. Dalam erti kata lain, ia berkait dengan persoalan etika dan integriti al-Raziq dalam mempersembahkan idea dan falsafah beliau berkenaan sastera Islami sama ada selari dengan Page $\mid 82$ 
tasawur Islami ataupun sebaliknya. Selain itu, penginterpretasian ini juga boleh difahami sebagai satu kaedah kefahaman beliau yang terbina menerusi kerangka Al-Qur'an dan Hadith dan proses penerapan serta pengaplikasian idea agar ia bersifat kritikal dan paling penting selaras dengan tuntutan wahyu.

Menyentuh berkenaan skop perbahasan pertama yang menjadi tumpuan al-Raziq iaitu berkenaan interaksi Islam terhadap al-Turath al-Islami, terdapat beberapa idea beliau yang dikenal pasti telah menginterpretasikan sumber Islam secara optimum. Antara idea tersebut adalah berkenaan interaksi sastera dengan al-Turath al- Ilmi yang merangkumi ilmu Islam secara khusus seperti ilmu fiqh dan ilmu Hadith. Selain itu, beliau juga tidak ketinggalan memberikan perhatian khusus kepada persoalan pemanfaatan dalam berurusan antara sastera dengan Al-Qur'an dan Hadith. Juga, tujahan idea beliau dalam skop al-Turath al-Islami memberikan penumpuan terhadap interaksi antara Islam dengan sumber rujukan utama dalam sastera dan yang terakhir iaitu interaksi Islam dengan teks-teks sastera. Berkenaan dengan interaksi sastera dengan al-Turath al'Ilmi, al-Raziq (2002:32) secara jelas telah memberikan panduan atau interpretasi sumber Islam beliau berkenaan isu ini apabila melontarkan langkah penting dalam pengharmonian interaksi dua hala antara sastera dan al-Turath al-Tlmi. Langkah penting dapat dilihat seperti di bawah:

$$
\begin{aligned}
& \text { جمع ودراسة الأقوال حول الأدب بوجه عام, والشعر على وجه أخص, ووظيفته, ومفهومه في البيئات } \\
& \text { العلمية المختلفة: الفقهاء والمحدثين, والمفسرين, وعلماء اللغة, مع العناية برصد تطورات المفهوم وتغيراته, } \\
& \text { من بيئة علمية لأخرى, ومن زمن لآخر , وبيان مدى ارتباط ذلك كله بالرؤية الإسلامية, ومدى تحققه } \\
& \text { بالصواب في الفهم الأدبي, مع بيان الأسباب العاملة في كل, سواء من ناحية تطورات المفهوم وتغيراته, } \\
& \text { أو مدى القرب والبعد من الرؤية الإسلامية والمفهوم الأدبي الصائب دون إغفال الظروف الملمة بنتاج } \\
& \text { هذه المفاهيم }
\end{aligned}
$$

Terjemahan:

Perlulah menghimpun dan mengkaji pendapat-pendapat berkenaan sastera secara umum dan puisi secara khusus beserta peranan dan konsepnya berdasarkan konteks lapangan ilmiah yang pelbagai seperti daripada kaca mata ahli fiqh, ahli hadith, ahli tafsir dan ahli bahasa dengan memberi penekanan kepada perkembangan konsep dan perubahannya daripada konteks ilmiah dan masa yang terkemudian. Justeru itu, hubungan kesemuanya itu perlulah dititik beratkan agar ia selari dengan pandangan Islam selagi mana ia mampu memberikan penjelasan yang betul dalam memahami sastera dan juga mampu menjelaskan faktor kepada berlakunya semua itu sama ada dari aspek perkembangan konsep dan perubahan ataupun kadar dekat atau jauh dengan pandangan Islam dan konsep sastera tanpa mengabaikan keadaan-keadaan yang menyumbang kepada terbinanya kefahaman tersebut.

Berkenaan dengan petikan yang dicetuskan oleh al-Raziq seperti yang dapat dilihat di atas, ia amat berkait rapat dengan gesaan beliau agar interaksi antara sastera dengan ilmu Islam yang bersifat khusus seperti ilmu fiqh dan Hadith dapat diharmonikan dan diletakkan dalam konteks yang betul iaitu selari dengan tuntutan wahyu. Ini dapat dilihat dengan tindakan al-Raziq yang telah menyenaraikan beberapa orang pengkritik sastera Islami yang begitu berhati-hati dalam menterjemahkan atau mengaplikasikan ilmu fiqh mahupun Hadith dalam perbahasan kritikan sastera mereka antaranya seperti ${ }^{\mathrm{c} A b d}$ al-Basit Badr dan Mustafa 'Ulyan. 'Abd al-Basit Badr dalam perbahasannya telah menerapkan idea berkenaan kepentingan kebudayaan kepada sasterawan muslim dan telah memperincikannya menurut hukum Islam dan merujuk secara terus kepada sumber autoriti yang menyentuh berkenaan hukum fiqh semasa (al-Raziq 2002:24). Begitu 
juga dengan Mustafa 'Ulyan yang telah mengaplikasikan idea beliau dengan menerapkan pandangan dan pendirian para ahli fiqh yang berautoriti seperti Imam Syafie, al-Syaukani, Ibn Hazm, al-Qurtubi berkenaan pandangan mereka terhadap puisi (al-Raziq 2002:26). Pemanfaatan oleh kedua-dua pengkritik sastera Islami ini boleh dijadikan contoh dalam melihat model interaksi dua hala yang bersifat harmoni antara sastera dengan ilmu Islam yang bersifat khusus. Justeru itu, dalam melihat keseriusan al-Raziq dalam menggembleng pemikiran beliau agar selari dengan tuntutan wahyu, gesaan dan langkah yang dikemukakan oleh beliau seperti dalam petikan di atas sewajarnya diperhalusi dan dinilai dengan sedalam-dalamnya mengikut acuan yang betul. Ini kerana menurut gesaan beliau terutamanya berkenaan penelitian para ilmuwan dalam pelbagai bidang seperti fiqh, hadith, tafsir serta hubung kait dengan sastera secara umum mahupun khusus merupakan satu bentuk manifestasi yang bakal mengundang kebaikan jika diuruskan dengan baik dan juga sebaliknya. Kesannya, ia amat terdedah kepada penyelewengan dan penyalahgunaan sumber Islami seperti yang dilakukan oleh Najib Mahfuz dalam novelnya Awlad Haratina (1959), Salman Rushdie dalam The Satanic Verses (1988), Langit Makin Mendung (1968) oleh Kipandjikusmin dan banyak lagi. Justeru itu, penyelewengan sebegini yang menjadi fokus kepada al-Raziq dalam menidakkan ia supaya tidak berlaku dan pada masa yang sama mengharmonikan interaksi antara sastera dan ilmu Islam pada konteks yang betul. Oleh yang demikian, penegasan beliau dalam memberikan pandangan berkenaan langkah untuk mengharmonikan interaksi dua hala tersebut merupakan manifestasi dan interpretasi terhadap kefahaman beliau dalam kerangka Al-Qur'an dan Hadith yang sebenar.

Beralih kepada idea seterusnya dalam ruang skop perbahasan berkenaan interaksi Islam terhadap al-Turath al-Ilmi, kajian ini selanjutnya menyelusuri perbahasan penting yang dikemukakan oleh al-Raziq berkenaan pemanfaatan dalam berurusan antara sastera dengan AlQur'an dan Hadith. Merujuk kepada perbahasan ini yang mengandungi sepuluh halaman seperti yang termaktub dalam buku Manhaj al-Islami fi al-Naqd al-Adabi, al-Raziq secara konsisten telah menginterpretasikan kefahaman beliau menurut kerangka Al-Qur'an dan Hadith yang sebenar. Penginterpretasian beliau dapat dikesan melalui beberapa idea yang dicerna dan dilahirkan beliau khususnya dalam mengangkat Al-Qur'an dan Hadith sebagai sumber Islam dan wahyu tertinggi yang tiada tandingan. Antara konsistensi al-Raziq dalam menginterpretasikan kefahaman beliau adalah ketika menyenaraikan parameter yang boleh dimanfaatkan oleh golongan sasterawan dan pengkritik Islami ketika berurusan dengan Al-Qur'an dan Hadith. Menerusi idea ini, beliau dilihat telah memberikan al-dhawabit ataupun parameter antaranya perlu bagi seseorang itu menjadikan kedua-dua sumber tersebut sebagai sumber perlembagaan kepada apa jua metodologi dan kaedah yang hendak diterapkan. Selain itu, al-Raziq juga menggesa supaya menjadikan kedua-dua sumber tersebut sebagai sumber dan punca utama untuk memperolehi ilmu pengetahuan (al-Raziq 2002:38). Dalam hal ini, Zulkarnain Mohamed (2010:93) menegaskan bahawa Al-Qur'an merupakan sumber tertinggi ilmu kerana ia merupakan kalam Allah S.W.T yang terpelihara daripada sebarang bentuk pengubahsuaian mahupun penyelewengan. Pada masa yang sama, Hadith pula berperanan sebagai pelengkap kepada Al-Qur'an dalam memberikan penjelasan maksud terhadap intipati mesej yang terdapat dalam kitabullah tersebut. Keterikatan hubungan dan perkaitan antara kedua-dua sumber tersebut pada realitinya sukar untuk dipisahkan bahkan ia menjadi satu piawaian yang telah dimeterai oleh Allah S.W.T dalam firman-Nya dan juga Hadith Rasulullah S.A.W terhadap keperluan berpegang teguh kepada kedua-dua sumber ini khususnya dalam melayari bahtera kehidupan di dunia. Justeru itu, dalam melihat kepentingan dan kesucian kedua-dua wahyu tertinggi ini, al-Raziq telah mengambil pendekatan untuk mengharmonikan kembali dan memberikan piawaian khusus berkenaan kaedah atau cara interaksi sastera terhadap kedua-dua sumber tersebut. Lanjutan daripada penginterpretasian idea beliau sebelum ini, alRaziq juga menggesa agar konteks keindahan gaya bahasa yang terdapat dalam Al-Qur'an dan Page | 84 
Hadith dapat diaplikasikan dan diterapkan secara langsung dalam penulisan sastera agar kehebatan gaya bahasa atau balaghah Al-Quran dan Hadith tersebut dapat dijelmakan dan dimanfaatkan bersama (al-Raziq 2002:38). Ini bagi menzahirkan kehebatan kalam Allah S.W.T yang mengandungi rahsia keajaiban yang tersendiri serta selayak dan sewajibnya bagi manusia untuk mengkaji dan menyelongkar khazanah keistimewaan tersebut supaya para manusia yang lain kelak dapat mengambil manfaat dan ibrah menerusi kedua-dua sumber tersebut. Secara keseluruhan, idea yang ditampilkan oleh al-Raziq khususnya dalam melihat interaksi sastera dengan Al-Qur'an dan Hadith telah diinterpretasi mengikut kerangka Islam yang sebenar dengan mengakui keagungan dan kebesaran kedua-dua sumber tersebut sebagai sesuatu yang perlu dihormati dan diletakkan pada posisi atau kedudukan yang setanding dengan hakikat kemukjizatannya.

Masih berlegar dalam skop perbahasan berkenaan interaksi Islam dengan al-Turath al-'Ilmi, perbahasan selanjutnya memberi tumpuan terhadap kaedah berinteraksi dengan sumber utama alTurath al-Adabi ataupun dikenali sebagai sumber rujukan kesusasteraan Arab yang muktabar. Menerusi bahagian ini, al-Raziq dilihat telah mengetengahkan mesej kritikan penting oleh pengkritik sastera terhadap metodologi yang digunakan oleh sasterawan terdahulu khususnya ketika menghasilkan buku yang dianggap sebagai rujukan penting kesusasteraan Arab masa kini. Dalam konteks ini, beliau telah menjadikan Walid al-'Azami dan bukunya yang bertajuk al-Sayf alYamani fi Nahr al-Asfahani Sabib al-'Aghani (1988) sebagai idea interpretasi sumber Islam berdasarkan kerangka Al-Qur'an dan Hadith. Dalam erti kata yang lain, beliau telah menjadikan Walid dan bukunya itu sebagai sampel untuk mengkritik Kitab al-'Aghani, sebuah rujukan kesusasteraan Arab yang cukup terkenal pada zaman terdahulu dan kini yang dikarang oleh Abi Farj al-Asfahani pada era kegemilangan Kerajaan Bani Abbasiyah. Justifikasi kritikan Walid terhadap Kitab al-'Aghani yang dikarang oleh al-Asfahani boleh dilihat menerusi petikan al-Raziq (2002:101) seperti yang tertera di bawah:

$$
\begin{aligned}
& \text { ثم يقول: ((من هنا بدأت أنظر إلى كتاب (الأغاني) نظرة جديدة, ورجعت إلى كتب التضعيف والتوثيق, } \\
& \text { والجرح والتعديل, فوجدت الأصفهاني رجلا غير مأمون)) ومن هنا أقبل على الكتاب يفتش فيه } \\
& \text { ليستخرج منه الروايات المكذوبة, ثم قام بفحص رجال السند الذين روى عنهم الأصفهاني, فإذا هم من } \\
& \text { الكذابين والمجروحين والمطعون عليهم, ثم قام بعزل أولئك الكذابين مع التعريف بهم, وإحصاء روايات } \\
& \text { الأصفهاني عنهم متسائلا:((وإذا كان أولئك الرواة يكذبون في رواية الحديث النبوي الشريف فكيف بكم } \\
& \text { في أخبار الناس, وقد توزعوا إلى مذاهب وفرق وطوائف تتجاذبهم الأهواء والمشارب والمنافع)). }
\end{aligned}
$$

Terjemahan:

Kemudian Walid berkata "Dari sini aku telah melihat Kitab al-Aghani dengan satu pandangan yang baru setelah aku merujuk kepada kitab-kitab yang memperihalkan berkenaan status perawi Hadith, al-Jarh wa al-Ta'dil, maka aku mendapati bahawa alAsfahani merupakan seorang lelaki yang tidak mempunyai integriti dalam dirinya". Selepas itu, kitab al-'Aghani tersebut dilakukan penelitian untuk dikeluarkan senarai riwayat-riwayat yang tidak sahih kemudian diperiksa perihal perawi sanad yang diriwayatkan mereka oleh al-Asfahani, maka ternyata kebanyakan perawi tersebut adalah mereka yang melakukan pendustaan, pembohongan dan menzalimi yang lain. Seterusnya, proses pengasingan dilakukan terhadap kesemua perawi tersebut dengam memerihalkan setiap satu daripada mereka dan membuat perkiraan terhadap riwayat-riwayat yang 
dikemukakan oleh al-Asfahani sambil mengemukakan pertanyaan, "Sekiranya kesemua perawi tersebut melakukan pendustaan terhadap Hadith-Hadith Nabi S.A.W, maka bagaimana keadaan mereka dalam meriwayatkan cerita-cerita manusia yang lain dan kemudiannya bertebaran dalam mazhab, kumpulan dan puak yang pelbagai yang dikelilingi dengan hawa nafsu".

Menerusi kutipan al-Raziq seperti yang tertera di atas, dapat dibuat rumusan bahawa Walid telah mempertikaikan kredbiliti al-Asfahani selaku pengarang Kitab al-'Aghani kerana telah mencampur adukkan Hadith-Hadith yang berstatus sahih dan dhaif ketika menyusun perbahasan dalam buku beliau tersebut. Hakikatnya, percampuran dan tidak keberhatian al-Asfahani boleh menimbulkan persepsi negatif khususnya di kalangan para pengkaji kesusasteraan Arab kerana buku tersebut merupakan antara rujukan terpenting dan muktabar dalam bidang pengkhususan kesusasteraan Arab. Kekurangan dan kelemahan yang ditonjolkan oleh beliau sedikit sebanyak telah menjejaskan reputasi Kitab al'Aghani sebagai sebuah rujukan yang mendapat tempat dan kedudukan tertinggi dalam dunia kesusasteraan Arab. Walau bagaimanapun, pendedahan Walid menerusi buku beliau yang bertajuk al-Sayf al-Yamani fi Nabr al-Asfahani Sabib al-'Aghani bukanlah untuk merendahkan martabat dan kedudukan al-'Aghani, tetapi paling penting adalah untuk mengkoreksi kembali kedudukan masdar al-Turath al-Adabi tersebut untuk lebih diyakini akan kesahihan dan keabsahan kandungan serta metodologi perbahasannya. Justeru, berdasarkan kepada fenomena kritikan Walid al-'Azami terhadap Kitab al-'Aghani karangan al-Asfahani, telah wujud secara langsung penginterpretasian sumber Islam yang cuba dilakukan oleh al-Raziq menerusi skop perbahasan interaksi Islam dengan sumber utama al-Turath al-Adabi. Melalui penginterpretasian ini, al-Raziq cuba menzahirkan kefahaman beliau berdasarkan kerangka AlQur'an dan Hadith berkenaan kewajipan untuk memilih Hadith yang sahih dan menyaring Hadith yang berstatus dhaif untuk dijadikan sumber penghujahan dalam metodologi penulisan atau perbahasan dalam buku. Refleksi daripada tindakan beliau ini pada satu sudut telah menatijahkan satu pemikiran Islam yang benar-benar sahih dan tulen. Paling penting, ia merupakan justifikasi yang paling tepat dalam menggambarkan keseriusan al-Raziq dalam mengakarkan kembali kesusasteraan Islami yang lebih tulen dan bebas daripada unsur-unsur yang meragukan apatah lagi yang jelas bertentangan dengan kehendak wahyu. Oleh yang demikian, pemilihan skop perbahasan ini dengan memfokuskan kritikan langsung Walid al-'Azami terhadap al-Asfahani merupakan interpretasi al-Raziq terhadap sumber Islam secara optimum dan menyeluruh.

Seterusnya, idea yang terakhir dikemukakan oleh al-Raziq berkenaan interaksi Islam dengan al-Turath al-Islami adalah kaedah Islam dalam berinteraksi dengan teks-teks sastera atau disebut sebagai al-Nusus al-Adabiyyah. Secara keseluruhannya, melalui perbahasan idea ini, beliau telah menginterpretasikan kefahaman beliau dengan mengemukakan dua kaedah yang bertepatan dengan roh Islam ketika hendak berinteraksi dengan teks-teks sastera. Pertama, menurut beliau, seseorang sasterawan ataupun pengkarya perlulah memilih dan meneliti sehabis mungkin potongan, rangkap mahupun perkataan untuk tujuan penciptaan puisi yang mempunyai pemaknaan dan roh yang berjiwa Islam (al-Raziq 2002:105). Dalam kaedah ini, al-Raziq memperjelaskan lagi bahawa pemaknaan yang berjiwa dan selaras dengan Islam tersebut bukan semata-mata dilihat dengan pemilihan perkataan mahupun ayat yang menunjukkan dilalah Islam secara langsung, akan tetapi ia perlu diperhalusi dan diteliti dalam konteks mesej dan pemaknaan Islam yang lebih meluas meliputi tersurat mahupun tersirat (al-Raziq 2002:105). Ini bagi mengelakkan pandangan yang berbentuk stereotaip yang sering membelenggu pemikiran golongan sasterawan mahupun pengkarya apabila mahu mencipta karya sastera Islami sama ada berbentuk puisi mahupun prosa. Menyentuh berkenaan kaedah kedua pula, al-Raziq (2002:107) menegaskan bahawa cara mengkaji dan menganalisis puisi perlulah diselaraskan mengikut 
kerangka yang betul dan tepat iaitu bertitik tolak daripada kerangka Islam yang benar. Ini kerana, menerusi analisis dan cara pandang yang tepat bersumberkan Islam sahaja yang mampu menatijahkan keputusan dan pertimbangan yang tepat. Kesimpulannya, dua kaedah yang diterapkan oleh al-Raziq dalam menangani interaksi Islam terhadap teks-teks sastera telah menatijahkan satu bentuk interpretasi sumber Islam oleh beliau secara langsung mahupun tidak langsung.

Menyentuh pula berkenaan skop perbahasan kedua iaitu interaksi Islam terhadap al-Turath al-Jahili, al-Raziq secara jelas telah memanfaatkan idea pemikiran beliau dengan menginterpretasikan sumber Islam berdasarkan kerangka Al-Qur'an dan Hadith. Menyentuh berkenaan al-Turath al-Jahili, secara asasnya ia merangkumi segala jenis pengetahuan, keilmuan, adat kebudayaan, kepercayaan, pegangan dan juga pengamalan oleh masyarakat Arab Jahiliyah sebelum muncul sinar Islam yang dibawa oleh junjungan Nabi Muhammad S.A.W (al-Raziq 2002:113). Dalam erti kata yang lebih tepat, kehidupan masyarakat Arab Jahiliyah sebelum diutuskan Baginda S.A.W adalah bermanifestasikan kepada sebuah kehidupan yang jauh daripada nur Islam dan cahaya hidayah yang benar. Maka tidak hairan, kehidupan masyarakat Arab ketika itu dipenuhi dengan kemaksiatan dan segala macam kerosakan seperti penzinaan yang berleluasa, pembunuhan, peperangan antara kabilah dan bermacam lagi sehinggalah diutuskan Nabi Muhammad S.A.W untuk membawa perubahan landskap kehidupan masyarakat tersebut dengan cahaya iman dan taqwa. Rentetan daripada justifikasi berkenaan gambaran kehidupan masyarakat Arab Jahiliyah tersebut, mungkin wujud tanggapan bahawa kesemua yang bersumberkan daripada al-Turath al-Jahili tersebut perlu ditinggalkan dan tidak wajar diaplikasikan. Kefahaman ini pada realitinya amat bercanggah dengan situasi sebenar yang wujud pada al-Turath al-Jahili tersebut. Justeru itu, al-Raziq dalam falsafah kritikan sastera Islami beliau berkenaan kaedah Islam dalam berinteraksi dengan al-Turath al-Jabili telah membina kaedah-kaedah tertentu yang boleh diaplikasikan terutamanya dalam menilai dan menyaring al-Turath al-Jabili dengan lebih tepat dan berwibawa. Antara kaedah tersebut menurut beliau, tidak semua yang datang daripada al-Turath tersebut perlu ditolak secara mentah, bahkan Islam membenarkan pengambilan dan pengadaptasian dilakukan secara berhemah dan berlegar dalam ruang sempadan yang dibenarkan. Ini termasuklah pengadaptasian al-Turath yang mampu memberikan kebaikan dan manfaat yang optimum sekaligus dapat mencernakan percambahan akal manusia yang cergas di samping menyucikan fitrah manusia kepada kebaikan (al-Raziq 2002:114). Di samping itu juga, al-Raziq (2002:115-116) dalam kaedahnya berkenaan interaksi terhadap al-Turath al-Jabili telah menggesa supaya merujuk kembali kepada pendirian Sahabat Rasulullah S.A.W dan para Tabi'in terhadap kesusasteraan Arab Jahiliyah. Ini kerana secara asasnya, metodologi dan prinsip yang dipegang oleh mereka adalah dengan meraikan dan saling bertolak ansur dalam ruang yang seluas-luasnya selagi mana tidak bercanggah dengan prinsip Islam dan tidak membawa kepada unsur yang menyesatkan. Ini penting bagi mengharmonikan dan memanfaatkan al-Turath itu sendiri terutamanya dalam konteks yang boleh menguntungkan dan memberi kelebihan kepada Islam secara langsung mahupun tidak langsung. Oleh yang demikian, berdasarkan beberapa kaedah yang dicetuskan oleh al-Raziq berkenaan interaksi Islam terhadap al-Turath al-jahili, dapat dirumuskan bahawa beliau cukup komited dan bersungguh-sungguh dalam menyaringkan kembali proses interaksi terhadap al-thurath tersebut agar dapat disesuaikan dan selari dengan tuntutan Islam. Ini juga secara realitinya dapat mengelakkan daripada berlaku keciciran idea dan pemikiran yang boleh diambil manfaat dan faedah walaupun berasal daripada pemikiran bukan Islam. Akhirnya, dapat disimpulkan bahawa al-Raziq telah melakukan interpretasi sumber Islam dengan tidak meminggirkan al-Turath al-Jahili secara mutlak bahkan telah memanfaatkan dengan kadar yang dibenarkan oleh Islam. 
Skop perbahasan ketiga atau yang terakhir pula akan menyentuh berkenaan interaksi Islam terhadap al-Turath al-Madi. Berbicara mengenai al-Turath al-Madi, ia boleh difahami sebagai satu bentuk pengetahuan, ilmu, seni, falsafah, aliran, pegangan dan juga pemikiran yang terdapat dalam tamadun lampau serta peradaban Barat yang sedang mengalami perkembangan pada masa kini (al-Raziq 2002:123). Ini juga termasuklah ideologi pemikiran dan kepelbagaian aliran dalam kesusasteraan moden yang pada realitinya tidak bertitik tolak dari Islam secara langsung seperti aliran realisme, eksistensialisme, simbolisme dan lain-lain lagi. Oleh yang demikian, dalam memastikan kelestarian interpretasi al-Raziq terhadap sumber Islam yang sebenar, beliau telah meneutralkan pandangan yang agak skeptikal terhadap aliran pemikiran yang datang dari Barat secara langsung dan juga mengkritik idea-idea utama dalam aliran tersebut yang bercanggah dengan Islam. Dalam hal ini menurut al-Raziq (2002:135-139), beliau tidak sekali-kali berkompromi dengan percanggahan dan penyelewengan yang wujud dalam kesusasteraan Barat dalam era moden ini. Dakwa beliau, intipati yang wujud dalam kesusasteraan tersebut majoritinya bertitik tolak dan bersumber dari pengaruh Yunani dan Rom yang amat mementingkan aspek material dan pemerolehan kuasa secara mutlak menerusi aktiviti ekonomi. Ini secara tidak langsung telah menyebabkan berlakunya jurang yang amat besar dalam hierarki masyarakat dan wujud penindasan dalam bentuk yang tidak disedari. Kesan lain yang timbul menerusi pengaruh Yunani dan Rom ini juga telah memperlihatkan pengabaian daripada aspek pembinaan jati diri manusia dan yang paling besar gagal memahami peranan sebenar yang perlu dimainkan dalam konteks perubahan sosial dalam masyarakat (al-Raziq 2002:136-137). Walaupun demikian, dalam konteks yang berlainan, aliran dan ideologi yang datang daripada Barat tersebut juga boleh dimanfaatkan dan disesuaikan mengikut kehendak dan kerangka Islam yang sebenar dan tepat. Ini dibuktikan dengan gesaan al-Raziq (2002:169) bahawa sebarang pengadaptasian dan pengambilan sebarang bentuk, idea mahupun istilah daripada Barat khususnya perlulah disesuaikan mengikut kerangka dan pandangan Islam. Ia juga tertakluk kepada kemampuan dan bakat yang ada pada seseorang sasterawan muslim untuk menterjemah dan mengadaptasikan idea Barat tersebut agar tidak terkeluar dalam ruang Islam yang dibenarkan. Justeru itu, dalam menanggapi dan menyaring segala bentuk aliran, pemikiran dan ideologi yang datang daripada Barat, al-Raziq telah mengambil sikap berhati-hati dan melakukan penilaian yang adil dalam menghakimi setiap implikasi yang bakal wujud berdasarkan pengamalan aliran tersebut secara langsung mahupun tidak langsung. Bertitik tolak daripada itu, dapat disimpulkan bahawa menerusi tindakan dan pandangan al-Raziq tersebut telah wujud penginterpretasian sumber Islam oleh beliau mengikut kerangka Islam yang tepat. Keadaan ini berlaku disebabkan oleh penerimaan secara berhemah dan cermat oleh beliau dalam menyaring setiap aliran yang datang daripada Barat tanpa mengambil pendekatan skeptikal yang diamalkan oleh para pengkritik kesusasteraan Islami yang lain.

\subsection{PENUTUP}

Justeru, secara keseluruhannya, perbahasan berkaitan penggemblengan sumber Islam oleh alRaziq telah memperlihatkan satu sisi yang berlainan dan mempunyai keistimewaan yang tersendiri. Ini dapat dilihat menerusi keseriusan dan kesungguhan beliau dalam memperincikan setiap manfaat dan kelebihan yang boleh diperolehi menerusi interaksi secara langsung dengan Al-Quran dan Hadith di samping beliau telah cuba menggunakan penginterpretasian sumber Islam berdasarkan elemen keetikaan khususnya dalam membahaskan pandangan Islam dalam skop al-Turath al-Islami, al-Turath al-jabili dan juga al-Turath al-Madi. Kesemua ini secara dasarnya merupakan interpretasi beliau terhadap kefahaman Islam yang bersumberkan al-Qur'an dan Hadith serta dijelmakan secara langsung dalam pembikinan falsafah kritikan sastera Islami beliau yang lebih bersifat tulen dan berasaskan nilai serta pandangan alam Islam. 


\section{Rujukan}

al-Quran al-Karim

Batahir, Bin cIsa (1998) Al-adab al-Islami wa naqdihi cind al-Syeikh Abi al-Hasan al-Nadwi. Islamiyyah AlMarrifah 12, 99-131.

Khalil, cImad al-Din (1998) Hawl harakah al-adab al-Islami al-mucasir: waqfah limurajacah al-hisab. Islamiyyah Al-Macrifah 12:11-37.

al-Raziq, Sayyid Sayyid cAbd (2002) Al-Manhaj al-Islami fi al-Naqd al-Adabi. Bayrut: Dar al-Fikr al Mucasir.

al-Raziq, Salah Sayyid cAbd (2015) Latar Belakang Dan Biografi Sayyid Sayyid cAbd al-Raziq. Temubual, 26 Oktober.

Zulkarnain Mohamed (2010) Al-Qur'an, Ilmu, Displin Islami dan Sastera. Dlm.Ungku Maimunah Mohd Tahir (pnyt). Kedudukan Ilmu dalam Kesusasteraan Teori \& Praktis, 83-157. Bangi: Institut Alam dan Tamadun Melayu, Universiti Kebangsaan Malaysia. 